ORNL/TM-1999/246

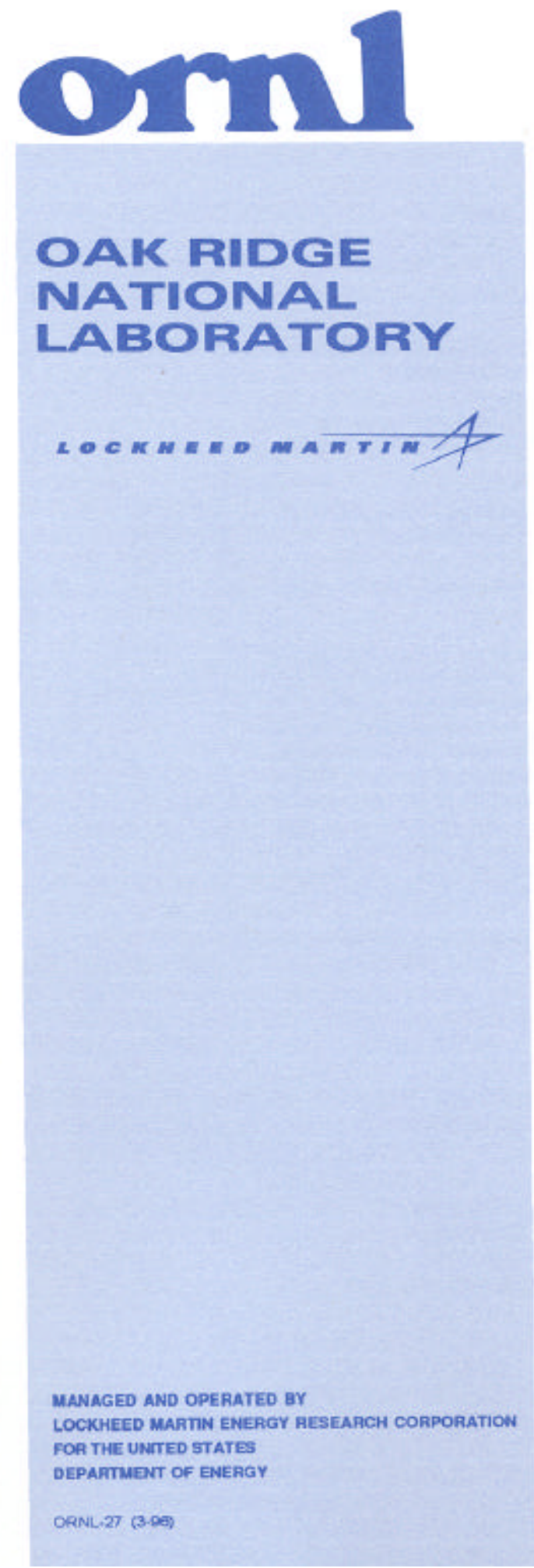

\title{
Review of Axial Burnup Distribution Considerations for Burnup Credit Calculations
}

\author{
J. C. Wagner \\ M. D. DeHart
}


This report has been reproduced directly from the best available copy.

Available to DOE and DOE contractors form the Office of Scientific and Technical Information, P.O. Box 62, Oak Ridge, TN 37831; prices available from (865) 576-8401.

Available to the public from the National Technical Information Service, U.S. Department of Commerce, 5285 Port Royal Rd., Springfield, VA 22161.

This report was prepared as an account of work sponsored by an agency of the United States Government. Neither the United States nor any agency thereof, nor any of their employees, makes any warranty, express or implied, or assumes any legal liability or responsibility for the accuracy, completeness, or usefulness of any information, apparatus, product, or process disclosed, or represents that its use would not infringe privately owned rights. Reference herein to any specific commercial product, process, or service by trade name, trademark, manufacturer, or otherwise, does not necessarily constitute or imply its endorsement, recommendation, or favoring by the United States Government or any agency thereof. The views and opinions of authors expressed herein do not necessarily state or reflect those of the United States Government or any agency thereof. 
ORNL/TM-1999/246

Computational Physics and Engineering Division

\section{Review of Axial Burnup Distribution Considerations for Burnup Credit Calculations}

J. C. Wagner

M. D. DeHart

Date Published: March 2000

Prepared by the

OAK RIDGE NATIONAL LABORATORY

Oak Ridge, Tennessee 37831 managed by

LOCKHEED MARTIN ENERGY RESEARCH CORP.

for the

U.S. DEPARTMENT OF ENERGY

under contract DE-AC05-96OR22464 



\section{CONTENTS}

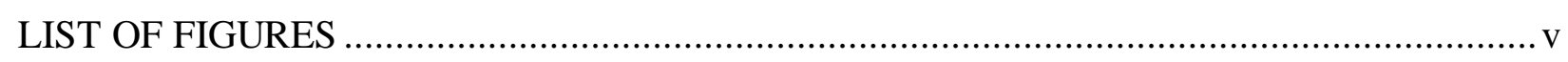

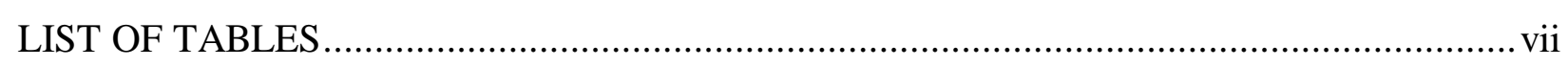

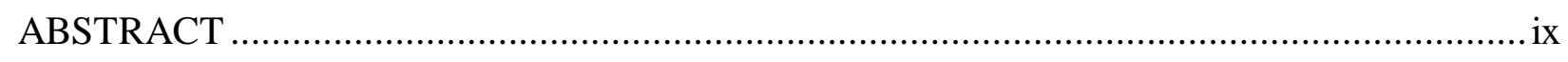

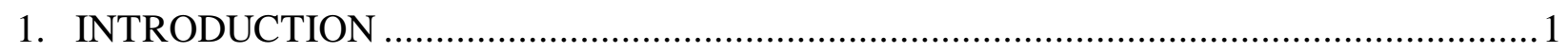

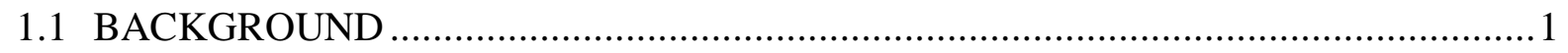

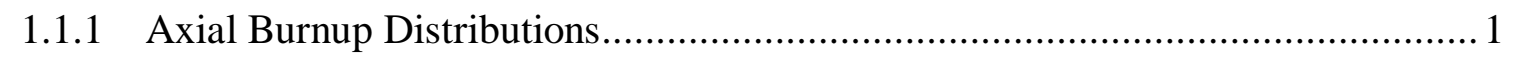

1.1.2 Definition of "End Effect"............................................................................ 3

1.1.3 Regulatory Perspective............................................................................. 4

2. REVIEW OF CURRENT KNOWLEDGE AND STATUS _.............................................

2.1 REACTIVITY EFFECT OF THE AXIAL BURNUP DISTRIBUTION.........................5

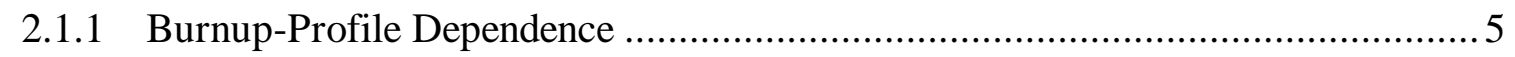

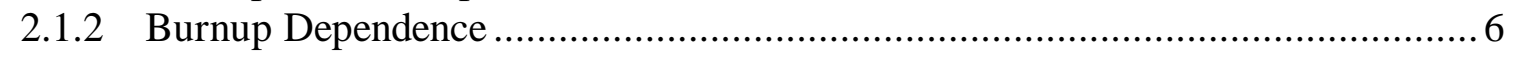

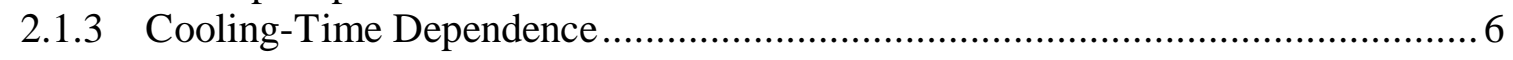

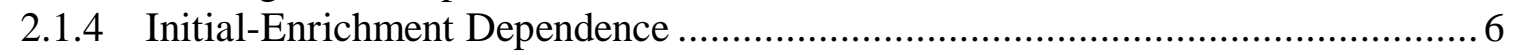

2.1.5 Individual Effect of Actinides and Fission Products........................................... 7

2.1.6 Operating-History Dependence... ............................................................... 7

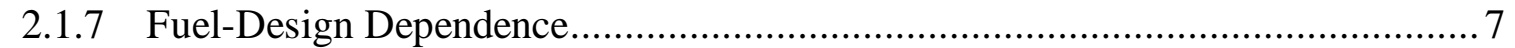

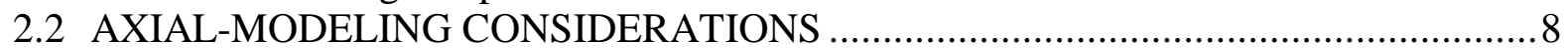

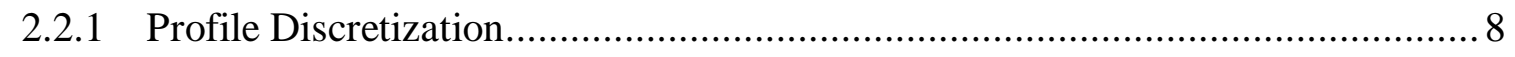

2.2.2 Monte Carlo Source Convergence ................................................................ 9

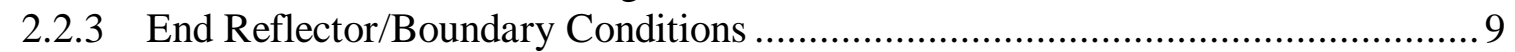

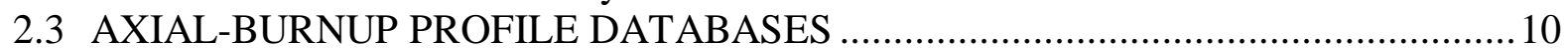

2.4 DETERMINATION OF BOUNDING AXIAL PROFILES ........................................ 11

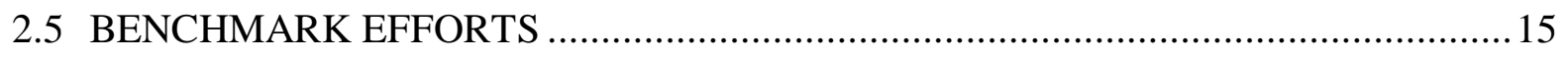

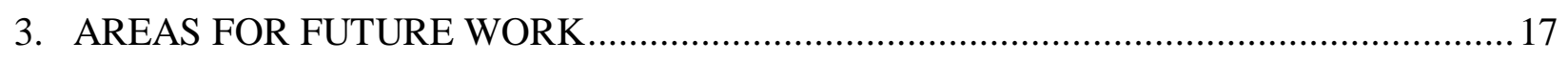

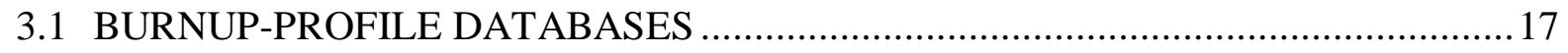

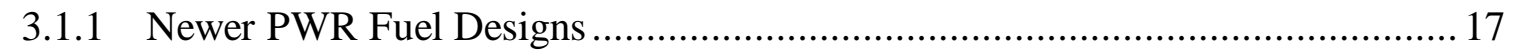

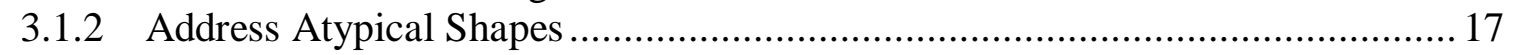

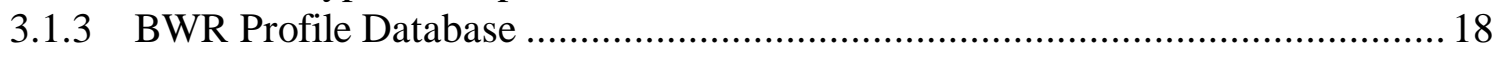

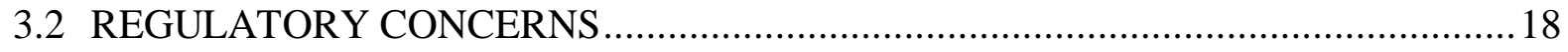

3.2.1 Bounding ....................................................................................... 18

3.2.2 $\quad$ Loading Specifications .......................................................................... 18

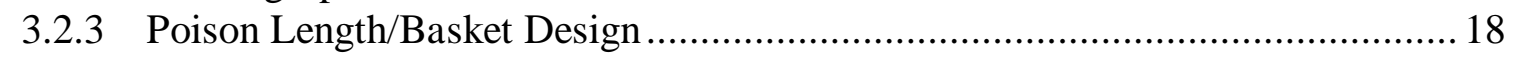

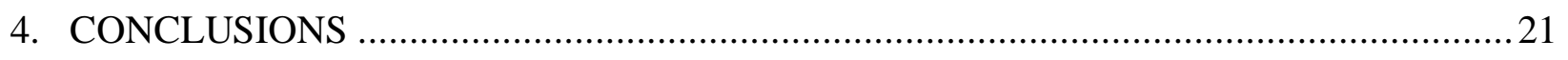

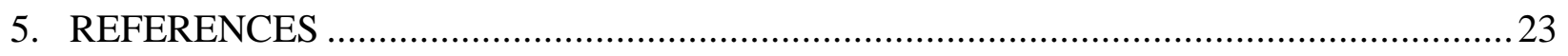





\section{LIST OF FIGURES}

\section{Figure}

Page

1. Representative normalized PWR axial burnup distribution ............................................2

2. Bounding axial profiles by burnup group. (Source: ref. 10) ........................................ 13

3. Proposed bounding axial profiles for DOE actinide-only burnup credit methodology.

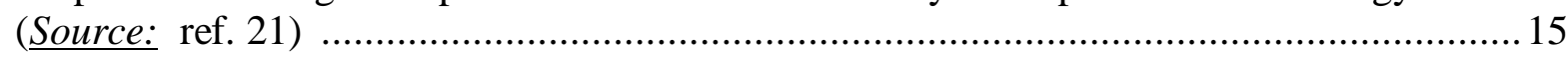





\section{LIST OF TABLES}

Table

Page

1. $\quad$ Bounding axial profiles by burnup group (Source: ref. 10) ......................................... 12

2. Proposed bounding axial profiles for DOE actinide-only burnup credit methodology

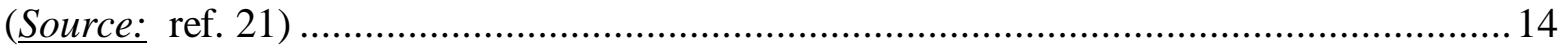

3. OECD phase $2 \mathrm{~A} \Delta k$ values (axial distribution vs uniform profile) .................................. 16 



\begin{abstract}
This report attempts to summarize and consolidate the existing knowledge on axial burnup distribution issues that are important to burnup credit criticality safety calculations. Recently released Nuclear Regulatory Commission (NRC) staff guidance permits limited burnup credit, and thus, has prompted resolution of the axial burnup distribution issue. The reactivity difference between the neutron multiplication factor $\left(k_{e f f}\right)$ calculated with explicit representation of the axial burnup distribution and $k_{\text {eff }}$ calculated assuming a uniform axial burnup is referred to as the "end effect." This end effect is shown to be dependent on many factors, including the axial-burnup profile, total accumulated burnup, cooling time, initial enrichment, assembly design, and the isotopics considered (i.e., actinide-only or actinides plus fission products). Axial modeling studies, efforts related to the development of axial-profile databases, and the determination of bounding axial profiles are also discussed. Finally, areas that could benefit from further efforts are identified.
\end{abstract}





\section{INTRODUCTION}

In the past, criticality safety analyses for spent fuel storage and transport canisters 1,2 assumed the spent fuel to be fresh (unburned) fuel with uniform isotopics corresponding to the maximum allowable enrichment. This "fresh-fuel assumption" provides a well-defined, bounding approach to the criticality safety analysis that eliminates all concerns related to the fuel operating history, thus, considerably simplifying the analysis. However, because this assumption ignores the decrease in reactivity as a result of irradiation, it is very conservative for fuel with significant burnup. The concept of taking credit for the reduction in reactivity due to fuel burnup is commonly referred to as burnup credit.

In contrast to criticality safety analyses that employ the fresh-fuel assumption, the utilization of credit for fuel burnup necessitates consideration of the fuel operating history, including the axial burnup distribution. Numerous studies have been performed to investigate and quantify the reactivity effect of axial burnup distributions. ${ }^{3-10}$ In general, these studies have shown that assuming a uniform axial distribution is conservative for low burnups, but becomes increasingly nonconservative as burnup increases. Hence to ensure that criticality safety margins are maintained, the reactivity effect of the axial burnup distribution must be addressed in a comprehensive and conservative manner. This report reviews the axial burnup distribution considerations important to burnup credit criticality safety calculations for pressurized-water reactor (PWR) fuel. Specifically, this report attempts to summarize current knowledge on the topic and identify areas that could benefit from further efforts. No new analyses are presented in this report. Even though axial burnup distributions also impact burnup credit thermal evaluations, this topic is outside the scope of this report, and therefore, is not addressed. Unless specifically stated otherwise, all discussions relate to PWR fuel with uniform axial enrichment.

Note that this report is intended to document the current knowledge and status of axial burnup distribution considerations important to burnup credit calculations. Hopefully, all significant and unique contributions to this topic have been included. However, because there has been considerable work performed in this area, including significant duplication, and there are numerous relevant publication venues, references to all relevant works may not be included.

\subsection{BACKGROUND}

\subsubsection{Axial Burnup Distributions}

The dynamics of reactor operation result in non-uniform axial-burnup profiles in fuel with any significant burnup. At the beginning of life in a PWR, a near-cosine axial-shaped flux will begin depleting fuel near the axial center of a fuel assembly at a greater rate than at the ends. As the reactor continues to operate, the cosine flux shape will flatten because of the fuel depletion and fission product buildup that occurs near the center. However, because of the high leakage near the end of the fuel, burnup will drop off rapidly near the ends. Partial-length absorbers or non-uniform axial fuel loadings can further complicate the burnup profile. In a boiling-water reactor (BWR), the same phenomena come into play $\frac{11}{11}$ but the burnup profile is complicated by 
the significant variation of axial moderator density and by non-uniform axial loadings of burnable poison rods.

The majority of PWR fuel assemblies have similar axial-burnup shapes - relatively flat in the axial mid-section (with peak burnup from 1.1 to 1.2 times the assembly average burnup) and significantly under-burned fuel at the ends (with burnup of 50 to $60 \%$ of the assembly average 12,13 Figure 1 shows a representative PWR axial burnup distribution. As is typical, the burnup is slightly higher at the bottom of the assembly than at the top. This variation is due to a difference in the moderator density. The cooler (higher density) water at the assembly inlet results in higher reactivity (which subsequently results in higher burnup) than the warmer moderator at the assembly outlet. Assemblies exposed to control rods or axial power shaping rods during their operating history deviate from this "typical" shape, but are not representative of the majority. The axial-burnup shape is dependent on a number of operating characteristics, and thus, significant variations between individual assemblies exist. Because the burnup shape has a strong influence on reactivity, these variations are important to criticality safety, and therefore, must be addressed.

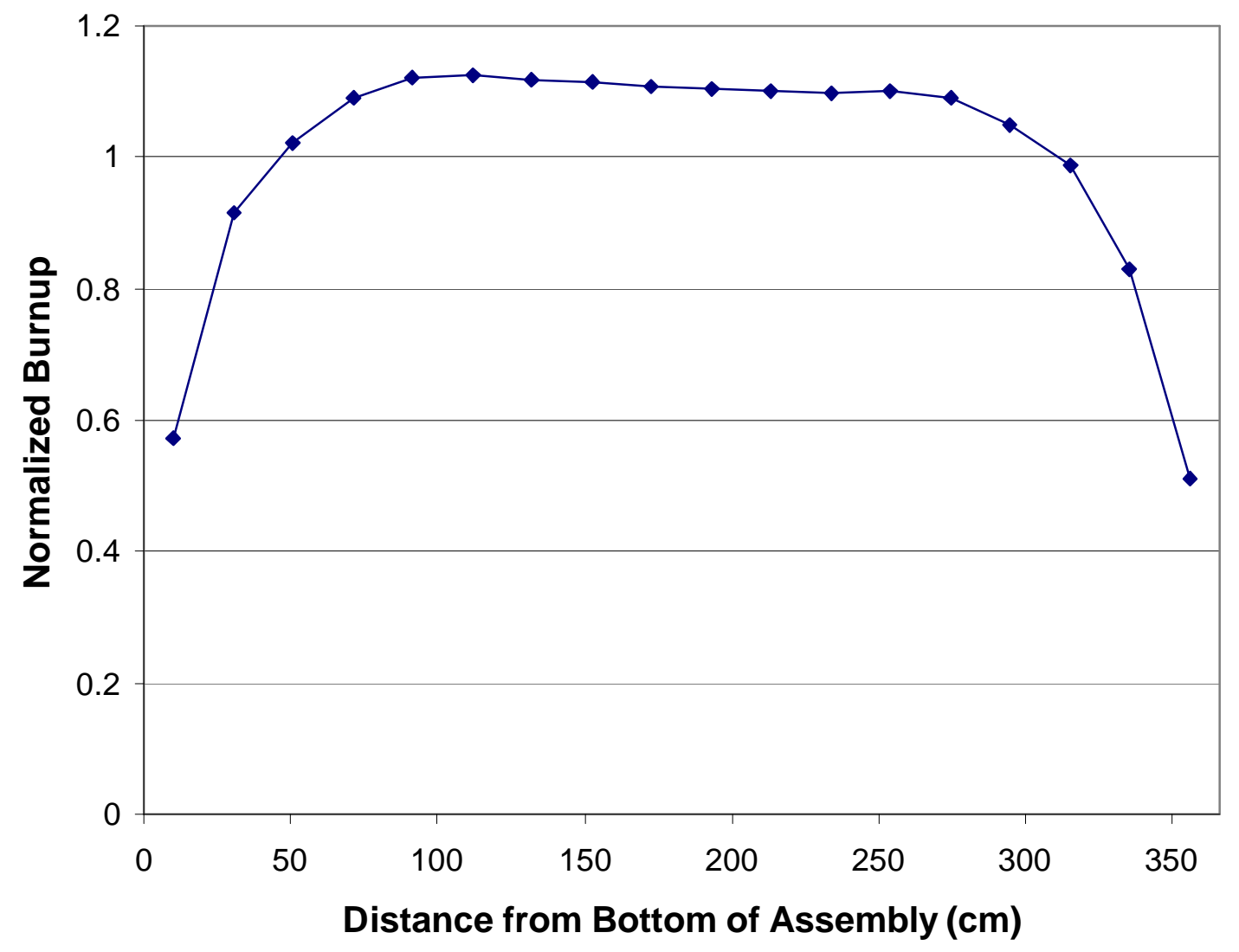

Fig. 1. Representative normalized PWR axial burnup distribution. 


\subsubsection{Definition of "End Effect"}

Under the fresh fuel assumption, the fuel composition is assumed to be uniformly distributed along the length of the assembly. The accumulated burnup for a spent fuel assembly is typically available (from plant data) in terms of an estimate of the axially averaged burnup. Although it is possible (and simpler) to calculate isotopic concentrations for the average burnup and assume that the material is uniformly distributed along the length of the assembly, this does not represent the actual burnup profile that exists in a spent fuel assembly. To accurately calculate the reactivity of spent fuel, the calculational model must include the axial distribution. Inclusion of the axial distribution can be done by axially segmenting the calculational model to approximate the axially varying isotopic concentrations, which correspond to the burnup in each axial segment. Although this representation of the axial burnup distribution is more accurate, it requires considerably more effort: additional depletion calculations (one for each axial segment of differing burnup) and complication of the criticality models.

Studies have shown that the value of $k_{\text {eff }}$ calculated assuming a uniform axial distribution is conservative for low burnups, but becomes increasingly nonconservative as burnup increases ${ }_{3-10,14-16}$ The transition between conservatism and nonconservatism depends on several factors, including the initial enrichment of the fuel, the cooling time considered, and the nuclides that are included in the criticality model, and appears to be strongly affected by fission product inventories 9,5

When assuming an axially uniform distribution of isotopics, the most reactive region of a fuel assembly is at the axial mid-plane, because leakage increases as one moves away from the center. In reality, the most reactive region of spent fuel is toward the assembly ends, where there exists a balance between reactivity due to lower burnup and increased leakage due to closer proximity to the fuel ends $\stackrel{4,6}{4}$ The reactivity difference between analyses with explicit representation of the axial burnup distribution and analyses that assume uniform axial burnup has become commonly known as the "end effect." $4,4,17$

For low burnups (i.e., below $20 \mathrm{GWd}$ /MTU), the fission density peaks at or near the axial center of the fuel. At this point, the decrease in reactivity with burnup is primarily driven by fuel depletion (i.e., a net reduction in fissile nuclides). At low burnup, the uniform axial burnup approximation distributes the burnup uniformly along the length of the fuel, which artificially decreases the fuel depletion at the center (where the fission density is greatest and effects due to leakage are significant) and increases the fuel depletion near the ends (away from the peak fission density). The artificial decrease in depletion in the region where the fission density is greatest causes a net increase in reactivity. As a result, the assumption of uniform axial burnup is more reactive for low burnups.

As burnup increases, the decrease in reactivity in the highly burned axial center results in a spatial shift in the peak fission density from the center toward the ends, where the burnup is substantially less. Thus, for high-burnup spent fuel in a storage or transport cask, the fission density is greatest in the low-burnup end regions. In contrast, the uniform axial burnup approximation artificially distributes the average burnup along the length of the fuel, which results in a peak fission density at the center, where the burnup has been artificially reduced (to the average). However, in reality (at high burnup) the fission density peaks near the ends where 
the burnup is significantly less than the average. The latter situation is more reactive, and therefore, the assumption of uniform axial burnup is less reactive for high burnups.

\subsubsection{Regulatory Perspective}

In the past, credit for fuel burnup was prohibited in criticality safety analyses for spent fuel storage and transport canisters 1,2 Criticality safety analyses necessarily assumed the fuel to be fresh (unburned) with uniform axial isotopics corresponding to the maximum allowable enrichment. Therefore, consideration of the axial distribution of burnup was not relevant to the analyses. Recently, however, an NRC staff guidance ${ }^{18}$ has been issued which permits partial credit for burnup in PWR fuel. In contrast to criticality safety analyses that do not credit fuel burnup, the utilization of credit for fuel burnup necessitates consideration of axial burnup distributions. In fact, ref. 18 states, "Of particular concern should be the need to account for the axial and horizontal variation of the burnup..."

In anticipation of regulatory acceptance of burnup credit for storage and transport canisters, and to address the issue of burnup credit in spent fuel pools where burnup credit has been allowed for some time, ${ }^{9,20}$ numerous studies $6-9$ [ 621 have been performed to quantify the reactivity effect of axial burnup distributions. However, to ensure criticality safety margins are maintained, the positive end effect must be addressed in a comprehensive and conservative manner. 18.21 


\section{REVIEW OF CURRENT KNOWLEDGE AND STATUS}

\subsection{REACTIVITY EFFECT OF THE AXIAL BURNUP DISTRIBUTION}

Axial variations in flux, which are mainly due to leakage at the fuel ends, result in a non-uniform burnup distribution along the axial length of the fuel. The axial distribution is characterized by end regions that are significantly under-burned with respect to the assembly-average burnup. The shape of the distribution is dependent upon the accumulated burnup, as well as other characteristics of the assembly operating history. For fuels of moderate-to-high burnup (i.e., burnups beyond approximately 20 to $30 \mathrm{GWd} / \mathrm{MTU}$ ), these under-burned regions are dominant in terms of reactivity, and thus, must be properly represented

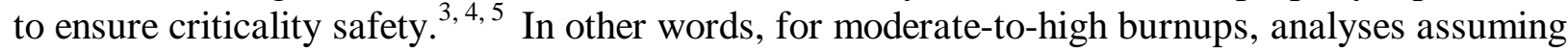
uniform axial burnup underestimate reactivity.

Numerous studies have been performed to quantify the end effect associated with axial burnup distributions. 6-9, 16,21 In general, these studies have shown that assuming uniform axial burnup is conservative for low burnups, but becomes increasingly nonconservative as burnup increases. The transition between conservative and nonconservative is dependent on numerous factors, but generally occurs in the burnup range of 20 to $30 \mathrm{GWd} / \mathrm{MTU}$. These studies concluded that for fuels of moderate-to-high burnup, the reactivity difference between analyses with explicit representation of the axial burnup distribution and analyses that assume uniform axial burnup is positive. As a very approximate rule-of-thumb, the effect is of the order of $1 \%$ $\Delta k / 10 \mathrm{GWd} / \mathrm{MTU}$ for burnups beyond the transition point. However, the amount by which the axial burnup distribution increases reactivity has been shown to be dependent upon many factors. The dependencies of the end effect on various important factors are discussed individually below.

\subsubsection{Burnup-Profile Dependence}

Neutron multiplication is driven by the production and loss of neutrons. In a finite system, such as a spent fuel cask, the peak neutron multiplication occurs at a location where neutron production is maximized while loss is simultaneously minimized. In fresh fuel, this peak occurs near the axial center. In spent fuel, the peak occurs away from the axial center, toward one or both ends of the fuel. At the axial center, production is diminished because of fuel depletion, and the loss is enhanced due to the burned-in presence of actinide and fission product absorbers. Moving away from the axial center, production increases as burnup decreases. However, leakage also increases as one moves toward the ends of the fuel. The most reactive region of the fuel, therefore, corresponds to a location near enough to the ends to take advantage of the less-burned and less-poisoned fuel, but far enough from the ends that leakage is reduced. This point in an assembly is strongly dependent on the ratio of burnup between the center and the ends, and thus is strongly dependent on the burnup shape or profile. Further, the end effect is dependent on the relative burnup at which this most reactive region occurs. Therefore, the magnitude of the end effect is primarily dependent on the slope of the axial-burnup profile near the ends of the fuel. 
Holding all other variables constant, variation in a selected burnup profile can result in differences of several percent in the calculated reactivity of a spent fuel assembly $4,6,10$ Consequently, a great deal of effort has been spent on investigating the reactivity effect of variations in the axial profiles, compiling actual axial-burnup profiles 12,13 and identifying and developing axial-burnup profiles that result in the greatest end effect $\frac{6,10}{6}$ The accumulation of actual burnup profiles is discussed in Sect. 2.3, and the determination of bounding axial profiles is summarized in Sect. 2.4

\subsubsection{Burnup Dependence}

In the absence of integral absorbers, the reactivity decreases nearly linearly with burnup. A typical axial burnup distribution is given in Fig. 1, which shows a maximum-to-average burnup of approximately 1.1 and a minimum burnup equal to approximately $50 \%$ of the average. The important point here is that the minimum burnup increases at a slower rate (approximately half) than the average burnup. As an example, if the average burnup increases by $30 \mathrm{GWd} / \mathrm{MTU}$, the minimum burnup will increase by only $15 \mathrm{GWd} / \mathrm{MTU}$. Therefore, while the ratio of minimum-to-average burnup remains constant, the difference between the two increases with accumulated burnup. This increase in the differential between minimum and average burnup is particularly important because the reactivity of a spent fuel assembly is controlled by the minimum burnup regions near the ends. In other words, because the reactivity decreases approximately linearly with burnup, the reactivity associated with the average burnup decreases faster than the reactivity associated with the minimum burnup. Consequently, the end effect increases with increasing burnup $3,5,14,16$

\subsubsection{Cooling-Time Dependence}

Calculations performed by various organizations demonstrate that the end effect increases with cooling time ${ }^{8,15}$ The buildup of stable actinide and fission product absorbers, due to the decay of actinides and fission products, tends to reduce reactivity. However, because the concentration of actinides and fission products is much greater in the fuel mid-region than in the fuel ends, this tends to increase the relative reactivity of the fuel ends compared with the fuel mid-region and results in an increase in the end effect. For cooling times of interest to transport and dry cask storage, ref. 22 indicates that only a few nuclides change significantly with cooling time. The buildup of ${ }^{155} \mathrm{Gd}$ and ${ }^{147} \mathrm{Sm}$ from other nonabsorbing fission products and the decay of ${ }^{241} \mathrm{Pu}\left(14.4\right.$ y half-life) to ${ }^{241} \mathrm{Am}$ contribute to the decrease in reactivity with increasing cooling time.

Additionally, DeHart ${ }^{16}$ has shown that increasing the cooling time results in a decrease in the transition point (i.e., the point in burnup at which the end effect becomes positive).

\subsubsection{Initial-Enrichment Dependence}

Although a relatively small effect, the transition point has been shown to increase with increasing initial enrichment. ${ }^{[16}$ Consistent with this finding, Parish ${ }^{10}$ and Brady ${ }^{14}$ have observed larger end effects with lower initial enrichments. Although no detailed comparisons with varying initial enrichments were found in the literature, it appears that the end effect increases with decreasing initial enrichment. However, this conclusion is contrary to observations in 
refs. 23 and 24, and therefore, the dependence of the end effect on initial enrichment should be investigated systematically.

\subsubsection{Individual Effect of Actinides and Fission Products}

A number of studies $6,9,16$ have been performed to isolate the individual influences of the actinides and fission products on the end effect. These studies have generally concluded that the positive reactivity effect exists in the absence of fission products, but that the fission products contribute substantially to the effect. In addition, fission products are shown to significantly influence other dependencies, (e.g., increase the cooling time and burnup dependencies). Because the fission product concentration is greatest in the mid-region of spent fuel, the inclusion of fission products increases the difference in reactivity between the mid-region and the fuel ends. Further, the fission product absorption worth increases with burnup.

Although discussions related to the determination of bounding axial-burnup profiles are deferred to Sect. 2.4, note here that Kang and Lancaster ${ }^{8}$ have concluded that the limiting axial-burnup profiles identified in a bounding analysis, which included actinides and fission products, $\frac{10}{10}$ were also valid for the actinide-only condition. However, because this later actinideonly ranking analysis was based on a comparison of relatively few axial-burnup profiles, further analysis may be required to fully justify this conclusion.

\subsubsection{Operating-History Dependence}

Many characteristics of the operating history impact the end effect. These characteristics include: the axial power and temperature distributions, the soluble boron concentration, and the control rod and/or burnable poison rod presence. These characteristics affect the discharge axial-burnup shape and the accumulation of actinides and fission products, which naturally impact the end effect. These characteristics may be accounted for through the use of bounding depletion parameters and bounding axial-burnup profiles.

\subsubsection{Fuel-Design Dependence}

All of the discussions in this report assume that the fuel assembly has uniform axial initial enrichment. Considering that most PWR fuel assembly designs utilize axially uniform enrichment, this is generally a valid assumption. However, there are a number of PWR fuel assembly designs that employ low-enrichment regions at the fuel ends. These regions typically correspond to the top and bottom 6 in. $(15.24 \mathrm{~cm})$ of the fuel assembly, contain either low-enrichment (e.g., $2.6 \mathrm{wt} \%{ }^{235} \mathrm{U}$ ) or natural uranium, and are referred to as "axial blankets." As a result of the axial blankets, these assemblies exhibit significantly different axial burnup distributions, which result in significantly reduced end effects. However, rather than developing a separate set of axial-burnup shapes for these assemblies designs, the axial blankets are currently ignored. ${ }^{8}$ This is a conservative approach that penalizes these axially heterogeneous designs for the sake of simplicity. Future consideration should be given to specifically address these designs to eliminate or reduce this penalty. 


\subsection{AXIAL MODELING CONSIDERATIONS}

In this section, issues associated with modeling the axial burnup distribution are discussed.

\subsubsection{Profile Discretization}

Given an appropriate bounding axial burnup distribution, which will be generally defined by 18-to-24 axial segments with constant burnup in each segment, 13 explicit calculations may be performed to determine the end effect. Specifically, a depletion calculation may be performed for each axial segment to determine the isotopic composition (18 to 24 depletion calculations), followed by a three-dimensional criticality calculation that includes the axial isotopic variation. In this approach, each of the axial segments or zones is treated independently (i.e., no spatial variation of depletion within an axial zone and no coupling between zones) in the depletion analysis. Recognizing that the axial-burnup profile is relatively flat in the fuel mid-section, analysts 4,7 have shown that the number of axial segments used to represent the axial profile may be reduced without introducing error. In particular, the axial segments or zones where the axial burnup does not vary significantly may be combined. This reduction in the total number of axial segments modeled reduces the number of depletion calculations required, and consequently, simplifies the analysis. For a typical PWR axial-burnup profile, DeHart concludes that approximately seven axial nodes are sufficient to capture the end effect.

Another issue of concern related to modeling the burnup profile is the proper representation of the rather large burnup slope near the ends of the fuel. In particular, the question arises as to whether the histogram representation associated with 18-to-24 axial regions is acceptable. To resolve this issue, DeHart has investigated the effect of increasing the number of axial regions (up to 100 uniform zones) and shown such efforts to be unnecessary.

Although the active fuel region in PWR fuel designs are approximately $12 \mathrm{ft}(365.76 \mathrm{~cm})$ in length, variations do exist. Therefore, when applying an axial-burnup profile, which is generally given as a percentage of axial height, to different fuel lengths, the length of each axial segment or zone is affected, and in the case of a longer fuel assembly, the length of each zone is increased. Physically, this results in an artificial change in the slope of the burnup profile. This is an artifact of the use of axial-burnup profiles based on a fixed number of zones that are independent of fuel length. While it may be fairly obvious, it is noted here for completeness that the end effect increases as the fuel length increases.

Axial modeling approximations made to-date are based on studies performed for limiting profiles derived from the PWR database. ${ }^{6,7} 10$ Expansion of the PWR database and/or the development of a new burnup profile database may require revised axial zoning studies to define the optimum number of zones for any revised form of axial-burnup profiles.

In terms of regulatory analyses, two general approaches have been proposed to bound the end effect. The first approach is to use the bounding axial-burnup profile in all calculations. This straightforward approach can be easily justified (once the bounding profile is established), but it requires significant computational effort in terms of depletion calculations and complications in the criticality models. The second approach is to determine the maximum 
positive reactivity effect (penalty) associated with the bounding axial-burnup profile and apply this penalty to all subsequent analyses, which assume a uniform axial burnup. The latter approach has significant advantages in terms of calculational simplicity, but is somewhat more difficult to justify as bounding for all potential configurations. Further, because the reactivity penalty will be determined and justified to be bounding for a number of configurations, it may also result in excess conservatism. Although both approaches have merits, it is likely that the first approach will find greater application because it is more easily justified.

\subsubsection{Monte Carlo Source Convergence}

Very early in the application of the Monte Carlo method for criticality safety calculations, difficulties were expected and observed for problems involving multiple source regions ${ }^{[25} \mathrm{The}$ difficulty is associated with the potential failure of the calculation to converge the source to the fundamental source mode and may result in an underestimation of the multiplication factor. Because the axial-burnup model is dominated by low-burnup (source) regions near the fuel ends, separated by high-burnup fuel, the question of potential source convergence problems must be addressed.

Analyses have been performed ${ }^{6,9}$ to investigate this and other issues associated with the use of the Monte Carlo method for criticality calculations including the axial burnup distribution. The work has shown that, provided an appropriately large number of neutron histories are considered to guarantee that the problem domain has been adequately sampled, the solution for the neutron multiplication factor will properly converge.

This issue of fission source convergence has also been considered in ref. 9, which showed that convergence problems become important for configurations with distributed burnup profiles. Specific analyses by Mitake and Osamu 9 showed that problems persisted when using too few histories per generation (300), regardless of increases in the total number of generations. However, the problems could be overcome through the use of sufficient histories per generation. Nevertheless, ref. 7 concludes that additional studies are needed to investigate this problem of convergence in more detail.

\subsubsection{End Reflector/Boundary Conditions}

Calculations performed in refs. 6 and 7 were based on simple axial models with a fixed set of boundary conditions. Because spent fuel reactivity is a function of both the burnup distribution and axial leakage, the boundary conditions (i.e., assembly or cask conditions at the end of the fuel) affect the end effect. In ref. 8, analyses are presented for various axial reflector assumptions, including pure water, 50/50 water and stainless steel combination, and a few specific cask designs. The behavior and magnitude of the end effect is shown to be dependent upon the axial materials and the cask size; maximums are observed for pure-water reflection and minimum cask size (i.e., a single assembly).

When using a bounding axial-burnup profile for all calculations, the dependency on the reflector materials is of no concern - they are inherently included in the cask model. However, to justify the use of a constant burnup penalty, as required in the second approach described in 
Sect. 2.2.1, it is necessary to determine a limiting cask configuration such that the end effect is bounded.

Regardless of the approach taken, the results in ref. 8 raise questions regarding the role of reflector materials in determining bounding axial profiles and the development of appropriate axial modeling approximations. Future work should study the impact of extreme boundary conditions (i.e., highly reflective, high leakage, or partially uncovered by poisons) on the determination of bounding profiles and axial zoning model nodalization.

\subsection{AXIAL-BURNUP PROFILE DATABASES}

The magnitude of the end effect is primarily dependent on the actual axial-burnup profile. However, in practice, the actual axial-burnup profile of each spent fuel assembly is not known. In general, only the assembly-average discharge burnup is known. Thus, to be conservative, one must identify an axial-burnup profile that is limiting in terms of the value of $k_{\text {eff, }}$, and yet realistic to the extent that it is not overly conservative, and thus, unnecessarily penalizing.

Naturally, the first step in addressing the variation in burnup shapes is to accumulate actual burnup distributions and assess the diversity of shapes. To this end, a database containing 3169 PWR axial burnup distributions has been compiled ${ }^{13}$ This database, which is the most comprehensive to date, includes profiles from three fuel vendors (Babcock \& Wilcox, Combustion Engineering, and Westinghouse) through the mid 1990s, four fuel array sizes $(14 \times 14,15 \times 15,16 \times 16$, and $17 \times 17)$, a burnup range of 3 to $53.3 \mathrm{GWd} / \mathrm{MTU}$, an enrichment range of 1.24 to $4.75 \mathrm{wt} \%{ }^{235} \mathrm{U}$, and represents 106 operating cycles. The fuel designs also contain a variety of absorbers. The profiles consist of burnups calculated by utilities and vendors for a discrete number (18 to 24) of axial segments based on core-follow calculations and in-core measurement data. Although the profiles are not measured directly, there is significant confidence that the profiles are representative of the actual fuel burnup.

With a database such as this, it is possible to quantify the end effect for various shapes, gain understanding into the relationship between the burnup shape and the end effect, and ultimately, determine bounding axial burnup distributions. To date, attempts to bound PWR profiles $\frac{10}{}$ have been based on the selection of a limited number of burnup-dependent profiles obtained from reactor operational data ${ }^{12,13}$ To our knowledge, no attempt has been made to define a bounding profile for BWR fuel assemblies due to the lack of a similar burnup database for BWR assemblies

Existing databases used to determine a limiting axial-burnup profile, such as that described in ref. 10, certainly have value in defining conservative profiles. However, the referenced database is limited to older assembly designs for PWR fuel only. If it is desirable to continue to determine bounding axial profiles on actual profiles from a database, then the existing database must be expanded to include a broader variety of fuel designs, especially some of the more recent fuel designs. Furthermore, since control rods, partial-length absorbers, and perhaps even neutron sources can have a significant effect on axial profiles, a decision must be made whether to include or exclude such designs from a database. Finally, provisions must be 
established to allow exclusion of profiles from a database if shapes are suspect due to known abnormal operating conditions or other considerations.

\subsection{DETERMINATION OF BOUNDING AXIAL PROFILES}

Previous work 6,8 in determining bounding axial burnup distributions has employed a relatively straightforward approach - perform criticality calculations for each burnup shape to determine the shape that produces the greatest reactivity.

Using the PWR database as a starting point, Parish et al 10 performed extensive analyses to determine bounding axial-burnup profiles. After excluding a number of burnup shapes for various reasons, the remaining burnup profiles were arranged into 12 burnup groups, each corresponding to a burnup range of $\sim 4 \mathrm{GWd} / \mathrm{MTU}$. One-dimensional diffusion calculations, assuming 35-cm-thick pure-water regions on either end of the fuel, were performed for each profile. Axially varying burnup was included by linear interpolation of 2-group assembly-averaged neutron cross sections, which were generated by CASMO-3. The results of the criticality calculations were used to rank the axial-burnup profiles in terms of their positive reactivity effect, and thus, identify the axial-burnup profiles that result in the greatest end effect.

Note, however, that the calculations for each assembly were performed with the actual assembly profile, initial enrichment and assembly-average discharge burnup. Therefore, the bounding profile evaluation 10 does not completely isolate the effect of the profile from the effects of variations in initial enrichment and discharge burnup. Even though the end effect is not strongly dependent on the initial enrichment and the discharge burnup, which cannot vary significantly with a burnup group (the width of all but two burnup groups is $4 \mathrm{GWd} / \mathrm{MTU}$; see Table 1), these variations should not be included. Future evaluations to determine bounding profiles should evaluate the burnup profiles consistently (i.e., at the same initial enrichment and burnup). Based on the calculational results and physical arguments, artificial bounding axial profiles were also defined for the twelve burnup groups. 10 These bounding axial profiles, taken directly from ref. 10, are listed in Table 1 and plotted in Fig. 2. The twelve bounding axial-burnup profiles were verified to be bounding through explicit criticality calculations.

Kang and Lancaster ${ }^{8}$ expanded that work to address bounding axial burnup distributions for actinide-only applications $\$ 21$ and to determine an overall bounding burnup distribution. Kang and Lancaster ${ }^{8}$ concluded that the limiting axial-burnup profiles identified in a bounding analysis, which included actinides and fission products, 10 were also valid for the actinide-only condition. However, this later actinide-only ranking analysis was based on a comparison of relatively few axial-burnup profiles, and thus, further analysis may be required to fully justify this conclusion. Additionally, bounding axial profiles for only three burnup ranges were defined and suggested for use with the proposed actinide-only burnup credit methodology. 21 For ease of comparison, these proposed profiles are listed in Table 2 and plotted in Fig. 3.

Although approximations may be made to reduce the number of depletion calculations necessary, the approach described above involves a significant number of depletion calculations followed by a large number of criticality calculations. These calculations involve a substantial amount of effort, which must be repeated as new axial burnup distribution databases are created 
and existing databases are updated and expanded. Therefore, future work should consider alternative means of determining bounding axial burnup distributions. Recent work in this area is given in refs. 27 and 28 .

Table 1. Bounding axial profiles by burnup group (Source: ref. 10 $)$

\begin{tabular}{|c|c|c|c|c|c|c|c|c|c|c|c|c|}
\hline groups & 1 & 2 & 3 & 4 & 5 & 6 & 7 & 8 & 9 & 10 & 11 & 12 \\
\hline A & \multicolumn{12}{|c|}{ Burnup ranges (GWd/MTU) } \\
\hline$(\%)$ & $>46$ & $42-46$ & $38-42$ & $34-38$ & $30-34$ & $26-30$ & $22-26$ & $18-22$ & $14-18$ & $10-14$ & $6-10$ & $<6$ \\
\hline 2.78 & 0.573 & 5 & 07 & 0.520 & 0.537 & 0.551 & 0.544 & 0.540 & 0.502 & 0.489 & 0.478 & 0.470 \\
\hline 8.33 & 917 & 918 & 914 & 0.888 & 0.895 & 0.886 & 0.869 & 0.860 & 0.817 & 0.772 & 0.773 & 0.775 \\
\hline 13.89 & 1.021 & 020 & 024 & 1.009 & 1.007 & 1.007 & 0.962 & 0.965 & 0.925 & 0.944 & 0.950 & 0.955 \\
\hline 19.44 & 040 & 45 & 41 & 1.046 & 1.045 & 0.974 & 0.918 & 0.921 & 0.796 & 0.857 & 059 & 1.064 \\
\hline 25.00 & 126 & 120 & 1.124 & 1.155 & 1.141 & 1.146 & 1.138 & 1.174 & 1.260 & 1.179 & 1.205 & 1.141 \\
\hline 30.56 & 123 & 112 & 117 & 1.143 & 1.140 & 1.138 & 1.140 & 1.176 & 1.254 & 1.151 & 1.201 & 1.162 \\
\hline & & & 8 & & 1 & & 53 & 11 & 242 & 1.186 & 11 & 80 \\
\hline 41.69 & 113 & 114 & 107 & 1.137 & 1.130 & 1.135 & 1.153 & 1.166 & 1.234 & 1.181 & 1.215 & 1.189 \\
\hline 47.22 & 109 & 104 & 103 & 1.137 & 1.125 & 1.138 & 1.172 & 1.167 & 1.277 & 1.180 & 1.218 & 1.192 \\
\hline 57.80 & 105 & 107 & 1.102 & 1.133 & 1.121 & 1.166 & 1.192 & 1.185 & 1.323 & 1.236 & 1.216 & 1.191 \\
\hline 58.33 & 101 & 101 & 1.099 & 1.130 & 1.138 & 1.173 & 1.201 & 1.188 & 1.336 & 1.261 & 1.209 & 1.185 \\
\hline 63.89 & 098 & 11 & 01 & 1.145 & 1.145 & 73 & 1.203 & 1.186 & 1.335 & 1.265 & 1.194 & 1.172 \\
\hline 69.44 & 101 & 107 & 111 & 1.145 & 1.142 & 1.169 & 1.199 & 1.182 & 1.325 & 1.261 & 1.170 & 1.158 \\
\hline 75.00 & 098 & 104 & 1.112 & 1.143 & 1.136 & 1.157 & 1.185 & 1.173 & 1.299 & 1.244 & 1.151 & 1.130 \\
\hline 80.56 & 1.028 & 25 & 1.029 & 1.025 & 1.020 & 22 & 1.014 & 1.008 & 0.756 & 0.951 & 0.976 & 1.021 \\
\hline 86.11 & 0.986 & 0.981 & 0.981 & 0.970 & 0.953 & 0.882 & 0.871 & 0.898 & 0.614 & 0.847 & 0.806 & 0.900 \\
\hline 91.67 & 0.831 & 0.800 & 0.823 & 0.743 & 0.738 & 0.701 & 0.689 & 0.669 & 0.481 & 0.650 & 0.596 & 0.714 \\
\hline 97.22 & 512 & 0.512 & .498 & 0.393 & 0.451 & 0.444 & 0.396 & 0.373 & 0.225 & 0.348 & 0.370 & 0.403 \\
\hline
\end{tabular}




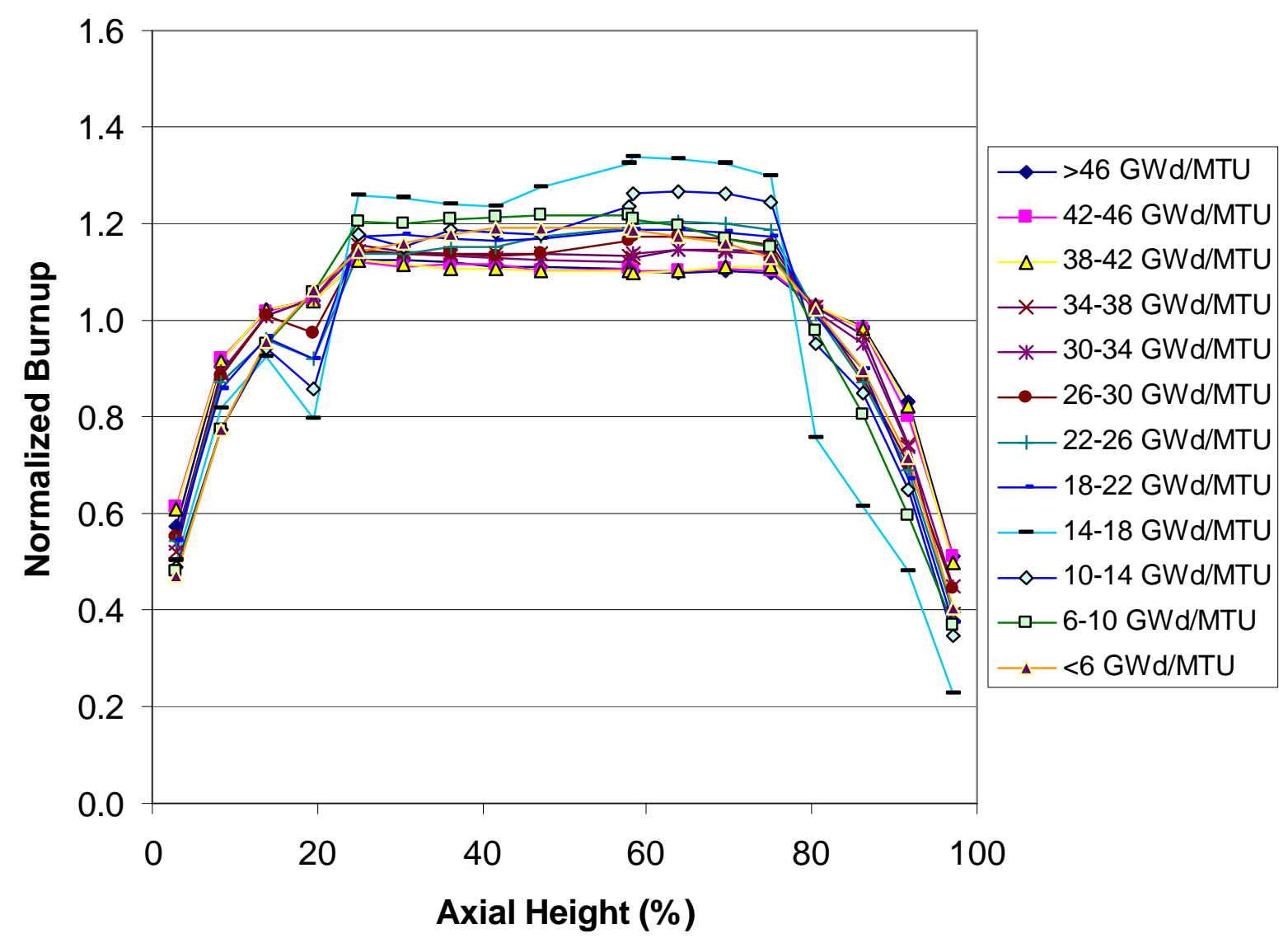

Fig. 2. Bounding axial profiles by burnup group. (Source: ref. 10) 
Table 2. Proposed bounding axial profiles for DOE actinide-only burnup credit methodology (Source: ref. 21

\begin{tabular}{cccc}
\hline Burnup groups & 1 & 2 & 3 \\
\hline Axial & \multicolumn{3}{c}{ Burnup ranges (GWd/MTU) } \\
\cline { 2 - 4 } height (\%) & $<18$ & $18-30$ & $<30$ \\
\hline 2.78 & 0.649 & 0.668 & 0.652 \\
8.33 & 1.044 & 1.034 & 0.967 \\
13.89 & 1.208 & 1.150 & 1.074 \\
19.44 & 1.215 & 1.094 & 1.103 \\
25.00 & 1.214 & 1.053 & 1.108 \\
30.56 & 1.208 & 1.048 & 1.106 \\
36.11 & 1.197 & 1.064 & 1.102 \\
41.69 & 1.189 & 1.095 & 1.097 \\
47.22 & 1.188 & 1.121 & 1.094 \\
57.80 & 1.192 & 1.135 & 1.094 \\
58.33 & 1.195 & 1.14 & 1.095 \\
63.89 & 1.190 & 1.138 & 1.096 \\
69.44 & 1.156 & 1.130 & 1.095 \\
75.00 & 1.022 & 1.106 & 1.086 \\
80.56 & 0.756 & 1.049 & 1.059 \\
86.11 & 0.614 & 0.933 & 0.971 \\
91.67 & 0.481 & 0.669 & 0.738 \\
97.22 & 0.284 & 0.373 & 0.462 \\
\hline
\end{tabular}




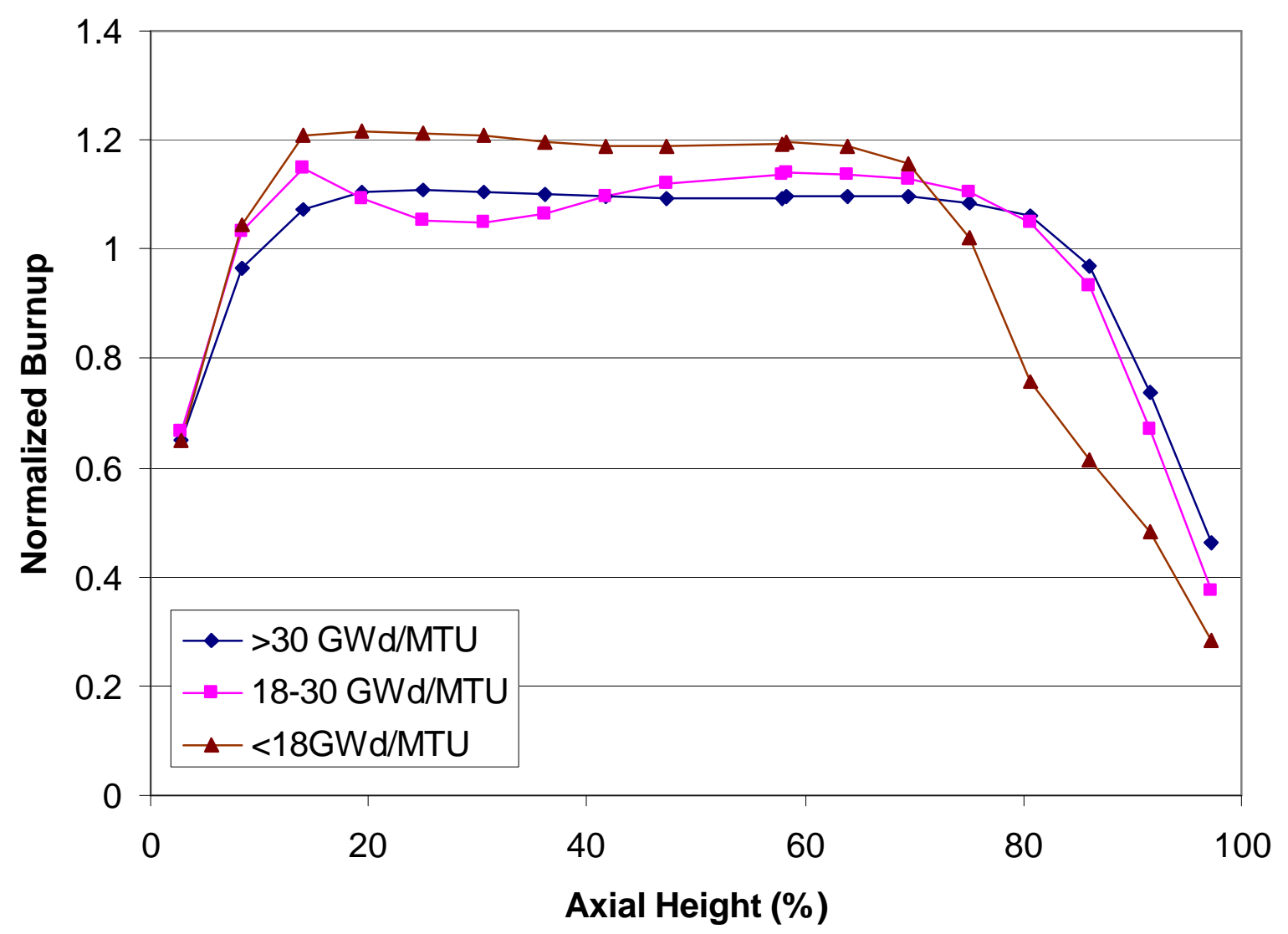

Fig. 3. Proposed bounding axial profiles for DOE actinide-only burnup credit methodology. (

\subsection{BENCHMARK EFFORTS}

The Nuclear Energy Agency of the Organization for Economic Cooperation and Development (OECD/NEA) sponsors a Working Group tasked with the study of burnup credit issues. The Burnup Credit Working Group (BUCWG) defines and analyzes computational benchmarks for the purpose of international comparison of different computer code/data packages used for the study of spent fuel analysis. The broad scope of international participants includes a wide range of codes, data, and methods for each benchmark problem. To date, the BUCWG has studied a number of different configurations relevant for burnup credit in light-water reactor fuel. Each of the studies (or phases) completed to date that include axial burnup distributions are briefly summarized below:

Phase $2 \mathrm{~A}^{16}$ - Criticality calculations were performed for a 3-D infinite-array lattice of PWR pin cells. This benchmark endeavored to study the effect of an axial-burnup profile in a multidimensional model. Twenty-two cases were analyzed, with varying enrichments and 
burnups. A single symmetric burnup profile was applied, broken into nine non-uniform heights. Local burnups for each region were assumed by multiplying a normalized burnup distribution by the assembly-averaged power. Calculations were performed with and without the profile, to assess the magnitude of the end effect.

Results reported by the various participants agreed to within $1 \% \Delta k$. Differences in cross-section treatments were believed to account for roughly half of this variation. The following observations were noted in the results with respect to the end effect: (1) it increases with increasing burnup and cooling time; (2) it is most pronounced when fission products are present; (3) the end effect is negative for low burnup and short cooling times, but becomes positive and of greater magnitude at higher burnup and longer cooling time; (4) the crossover from negative to positive occurs around $25 \mathrm{GWd} / \mathrm{MTU}$ when fission products are present, and near $30 \mathrm{GWd} / \mathrm{MTU}$ when fission products are not modeled; and (5) the crossover from negative to positive occurs at slightly higher burnup when fuel enrichment increases.

Phase $2 \mathrm{~B}^{9}$ - Criticality calculations were performed in a conceptual spent fuel cask configuration. This phase employed the same axial models and isotopics as were used in Phase $2 \mathrm{~A}$, but only nine higher burnup cases were analyzed, with fuel at an enrichment of $4.5 \mathrm{wt} \%$. The model consisted of a set of 21 assemblies, using axially symmetric spent fuel isotopic specifications but within an axially asymmetric cask. Poison plates were modeled between fuel assemblies.

From this study, the following observations were made: the end effect increases with increasing burnup, and, in general, the same trends observed in Phase 2A were also noted in the cask model. Table 3 shows the magnitude of the end effect for two burnups, with and without fission products present in the model.

Table 3. OECD phase 2A $\Delta k$ values (axial distribution vs uniform profile)

\begin{tabular}{ccc}
\hline Burnup & Fission products included? & $\Delta k(\mathrm{k}$ (profile)-k(uniform)) \\
\hline 30 & Yes & 0.003 \\
30 & No & -0.006 \\
50 & Yes & 0.031 \\
50 & No & 0.007 \\
\hline
\end{tabular}




\section{AREAS FOR FUTURE WORK}

The recently released NRC staff guidance, which permits limited burnup credit, necessitates prompt resolution of the axial burnup distribution issue. Of interest is the establishment of a conservative, yet reasonable, and defendable methodology to account for the axial burnup end effect. Although significant effort has been spent on this topic, areas that could benefit from further attention are briefly discussed below.

\subsection{BURNUP PROFILE DATABASES}

Existing databases used to determine a limiting axial-burnup profile, such as that described in ref. 10, certainly have value in defining conservative profiles. However, the referenced database is limited to older assembly designs for PWR fuel only. If bounding profiles are to be based on a survey of actual burnup profiles from a database, the existing database must be expanded to include a broader variety of fuel designs, especially some of the more recent fuel designs with higher enrichments and greater burnup. Furthermore, since control rods, partial length absorbers, and perhaps even neutron sources can have a significant effect on axial profiles, a decision must be made whether to include or exclude such designs in a database. Finally, provisions must be established to allow exclusion of profiles from a database if shapes are suspect due to known abnormal operating conditions or other considerations.

\subsubsection{Newer PWR Fuel Designs}

Although the basic shape of the axial-burnup profile is expected to remain unchanged, axial effects associated with new fuel designs must also be considered. In particular, newer fuel designs will likely employ more extensive use of integral absorbers, burnable poison rods, and axially varying enrichments. Although these newer designs may possibly have a lower associated end effect, they must be properly considered.

\subsubsection{Address Atypical Shapes}

Axial-burnup profiles may be significantly affected by a number of operating history characteristics, including the use of control rods and axial power shaping rods. As a result, the number of possible unique profiles is nearly infinite. Therefore, it is not possible to demonstrate that bounding axial profiles based on a finite number of profiles in a database will be bounding for all spent nuclear fuel assemblies. Further, it may be impractical or excessively conservative to develop artifical bounding axial profiles based on atypical shapes. Subsequently, a strategy for dealing with potentially unrepresented, atypical assemblies must be developed. One possibility might be to demonstrate, through criticality calculations, that the effect of loading one or two atypical assemblies into a cask is negligible. If this is verified to be the case, the use of bounding axial profiles based on a finite database may be justified by consideration of the expected number of atypical assemblies and the possibility of loading them in close proximity.

Previous bounding analyse ${ }^{10}$ have excluded profiles that were considered to be inappropriate. Although this practice is generally reasonable, unambiguous provisions must be developed to address the exclusion of profiles from consideration. 


\subsubsection{BWR Profile Database}

Due to reasons associated with long-term disposal and economic canister design, burnup credit for BWR spent fuel has recently gained interest $!^{111}[2,30$ While measured axial burnup

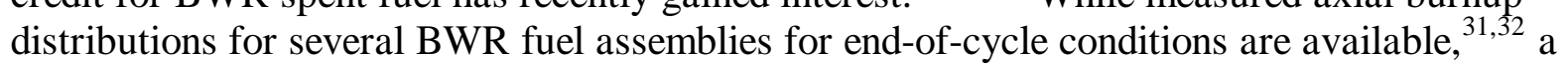
database similar to that developed for PWR fuel is needed. The fact that BWR fuel assemblies are manufactured with variable enrichments both radially and axially, are exposed to timevarying void distributions, contain integral burnable poison rods, and are subject to partial control blade insertion during operation means that BWR profiles are likely to have more variation than that observed for PWR fuels. Thus, a large database may be necessary to capture all of the important characteristics.

\subsection{REGULATORY CONCERNS}

To ensure criticality safety margins are maintained, the reactivity effect of the axial burnup distribution must be addressed in a comprehensive and conservative manner. This necessitates the use of a calculational approach that properly addresses all of the assemblies that are to be considered as acceptable contents in the storage/transport canister. Thus, the choice of a bounding axial profile is related to the anticipated canister contents and procedures are necessary, either through measurement or possibly stringent administrative controls, to ensure that the loaded contents are consistent with the analyses prior to loading.

\subsubsection{Bounding Analysis}

As discussed in Sect. 3.1, issues remain in the justification of employing bounding axial profiles based on a finite database of older fuel assembly designs. Although these issues may be eliminated through administrative constraints (e.g., exclusion of fuel assemblies with particular design or operating history characteristics), they must ultimately be addressed. Although detailed consideration of these issues may not be necessary in the realm of actinide-only credit, due to the known reactivity margin associated with the presence of fission products, it will become more important when credit for fission products is sought.

\subsubsection{Loading Specifications}

Ultimately, some form of limiting axial profile will be assumed, whether it is based on database analysis or theoretical derivations. However, it may remain desirable to verify at fuel loading time that the burnup profile of an assembly is bounded by the assumed profile used in safety analyses. It is possible that an adjoint analysis of a selected bounding profile may be mathematically folded with measured profiles from real assemblies to ensure that the measured profile is within the acceptance criterion set by the bounding profile. This is a conceptual approach at this time and has not yet been developed or tested for feasibility. However, given the uncertainties in axial effects and the wide variety of axial-burnup profiles in the spent fuel inventory, it may be advantageous to explore this possibility.

\subsubsection{Poison Length/Basket Design}

As discussed throughout this report, credit for fuel burnup introduces concerns that were not present in criticality safety analysis with the fresh-fuel assumption. These new concerns 
arise due to the reduction in reactivity margin and impact on the physical characteristics of the problem as a result of taking credit for fuel burnup. When employing the fresh-fuel assumption, the most reactive area corresponds to the axial center of the fuel. However, with credit for fuel burnup, the most reactive areas correspond to the fuel ends. The change to the physical characteristics of the problem focuses attention on the fuel ends, and subsequently has raised concerns related to the neutron absorber length. Specifically, situations in which end portions of the fuel assemblies are not separated by fixed neutron absorber panels are of concern.

Although this is also a concern with the fresh-fuel assumption, it has received additional attention in the context of burnup credit due to the reduction in reactivity margin. Nevertheless, this issue should be considered a canister-specific design safety issue and not a generic burnup credit issue. Further, where reliance on fixed neutron absorber panels is utilized, canister designs should be required to employ mechanical means, such as the use of appropriate neutron absorber panel lengths and/or rigid spacers above and/or below the fuel assemblies, to ensure fuel assemblies are separated by the neutron absorber panels over the entire axial length. Otherwise, specific analyses, which demonstrate the safety of the design, must be performed and reviewed. The canister design requirement appears to be a simpler and more easily justified approach to this problem. 



\section{CONCLUSIONS}

Axial variations in flux, which are primarily due to leakage at the fuel ends, result in a non-uniform burnup distribution along the length of the fuel. Numerous studies have been performed to investigate and quantify the reactivity effect of axial burnup distributions. In general, these studies have shown that assuming a uniform axial distribution is conservative for low burnups, but becomes increasingly nonconservative as burnup increases. Thus, to ensure criticality safety margins are maintained, the reactivity effect of the axial burnup distribution must be addressed in a comprehensive and conservative manner. This report has reviewed the axial burnup distribution considerations important to burnup credit calculations for PWR fuel. Specifically, the current knowledge on the topic was summarized and areas that could benefit from further effort were identified.

Note that this report is intended to document the current knowledge and status of axial burnup distribution considerations important to burnup credit calculations. Hopefully, all significant and unique contributions to this topic have been included. However, because there has been considerable work performed in this area, including significant duplication, and there are numerous relevant publication venues, references to all relevant works may not be included. 



\section{REFERENCES}

1. $\quad$ Standard Review Plan for Dry Cask Storage Systems, NUREG-1536, U.S. Nuclear Regulatory Commission, Washington, D.C., January 1997.

2. Standard Review Plan for Transportation Packages for Spent Nuclear Fuel - Draft Report for Comment, NUREG-1617, U.S. Nuclear Regulatory Commission, Washington, D.C., March 1998.

3. B. H. Wakeman and S. A. Ahmed, Evaluation of Burnup Credit for Dry Storage Casks, EPRI NP-6494, Electric Power Research Institute, August 1989.

4. M. C. Brady, C. V. Parks, and C. R. Marotta, "End Effects in the Criticality Analysis of Burnup Credit Casks," Trans. Am. Nucl. Soc. 62, 317 (1990).

5. S. E. Turner, "An Uncertainty Analysis - Axial Burnup Distribution Effects," Proc. Workshop Use of Burnup Credit in Spent Fuel Transport Casks, Washington D.C., February 21-22, 1988, SAND89-0018, TTC-0884, UC-820, T. L. Sanders, Ed., Sandia National Laboratories, October 1989.

6. M. D. DeHart, Sensitivity and Parametric Evaluations of Significant Aspects of Burnup Credit for PWR Spent Fuel Packages, ORNL/TM-12973, Lockheed Martin Energy Research Corp., Oak Ridge Natl. Lab., May 1996.

7. M. D. DeHart, Parametric Analysis Of PWR Spent Fuel Depletion Parameters For Long-Term Disposal Criticality Safety, ORNL/TM-1999/99, Lockheed Martin Energy Research Corp., Oak Ridge Natl. Lab., October 1999.

8. C. H. Kang and D. B. Lancaster, "Actinide-Only Burnup Credit for Pressurized Water Reactor Spent Nuclear Fuel - III: Bounding Treatment of Spatial Burnup Distributions," Nucl. Technol. 125, 292 (1999).

9. A. Nouri, OECD/NEA Burnup Credit Criticality Benchmark - Analysis of Phase II-B Results: Conceptual PWR Spent Fuel Transportation Cask, IPSN/98-05 (NEA/NSC/DOC(98)1), Institut de Protection et de Surete Nucleaire, May 1998. 
10. T. A. Parish and C. H. Chen, Bounding Axial Profile Analysis for the Topical Report Database, Nuclear Engineering Dept, Texas A\&M University, March 1997.

11. J. C. Wagner, M. D. DeHart, and B. L. Broadhead, Investigation of Burnup Credit Modeling Issues Associated with BWR Fuel, ORNL/TM-1999/193, Lockheed Martin Energy Research Corp., Oak Ridge Natl. Lab., October 1999.

12. R. J. Cacciapouti and S. Van Volkinburg, Axial Profile Database for the Combustion Engineering $14 \times 14$ Fuel Design, YAEC-1918, Yankee Atomic Electric Company, April 1995.

13. R. J. Cacciapouti and S. Van Volkinburg, Axial Burnup Profile Database for Pressurized Water Reactors, YAEC-1937, Yankee Atomic Electric Company, May 1997.

14. M. C. Brady and T. L. Sanders, "A Validated Methodology for Evaluating Burnup Credit in Spent Fuel Casks," pp. II-68-II-82 in Proc. International Conference on Nuclear Criticality Safety, Christ Church, Oxford, United Kingdom, September 9-13, 1991.

15. T. L. Sanders, R. M. Westfall, and R.H. Jones, Feasibility and Incentives for the Consideration of Spent Fuel Operating Histories in the Criticality Analysis of Spent Fuel Shipping Casks, SAND87-0151, TTC-0713, UC-71, Sandia National Laboratories, August 1987.

16. M. Takano and H. Okuno, OECD/NEA Burnup Credit Criticality Benchmark - Result of Phase IIA, JAERI-Research-96-003 (NEA/NSC/DOC(61)01), Japan Atomic Energy Research Institute, 1996.

17. M. C. Brady, T. L. Sanders, K. D. Seager, and W. H. Lake, "Burnup Credit Issues in Transportation and Storage," Vol. 1, pp. 39-46 in Proc. 10th International Symposium on Packaging and Transportation of Radioactive Materials, Yokohama City, Japan, September 13-18, 1992.

18. "Interim Staff Guidance - 8, Rev. 1 - Limited Burnup Credit," U.S. Nuclear Regulatory Commission, Spent Fuel Project Office, August 1999. 
19. "Guidance on the Regulatory Requirements for Criticality Safety Analysis of Fuel Storage at Light-Water Reactor Power Plants, NRC memorandum from L.I. Kopp to T. Collins, August 19, 1998, U.S. Nuclear Regulatory Commission.

20. S. E. Turner, "Storage of Burned PWR and BWR Fuel," Trans. Am. Nucl. Soc. 55, 394 (1987).

21. “Topical Report on Actinide-Only Burnup Credit for PWR Spent Nuclear Fuel Packages," DOE/RW-0472, Rev. 2, U.S. Department of Energy, September 1998.

22. B. L. Broadhead, M. D. DeHart, J. C. Ryman, J. S. Tang, and C. V. Parks, Investigation of Nuclide Importance to Functional Requirements Related to Transport and LongTerm Storage of LWR Spent Fuel, ORNL/TM-12742, Lockheed Martin Energy Research Corp., Oak Ridge Natl. Lab., June 1995.

23. Y. Naito, M. Takano, M. Kurosawa, and T. Suzaki, "Study of the Criticality Safety Evaluation Method for Burnup Credit in JAERI," Nucl. Technol. 110 (1995).

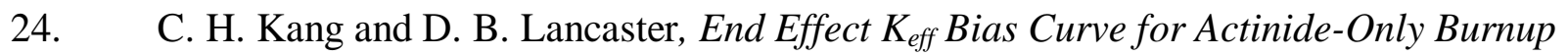
Credit Casks, DOE/RW-00134, U.S. Department of Energy (1997).

25. G. E. Whitesides, "A Difficulty in Computing the k-effective of the World," Trans. Am. Nucl. Soc. 14, 680 (1971).

26. Determination of the Accuracy of Utility Spent Fuel Burnup Records - Interim Report, EPRI TR-109929, Electric Power Research Institute, Aplo Alto, Calif., May 1998.

27. J. C. Neuber, "Burnup Credit Applications to PWR and BWR Fuel Assembly Wet Storage Systems," Int. Conf. Physics of Nuclear Science and Technology, Long Island, New York, October 5-8, 1998.

28. M. Maillot, E. Guillou, D. Biron, and S. Janski, "Search for an Envelope Axial Burnup Profile for Use in PWR Criticality Studies with Burnup Credit," Sixth Int. Conf. on Nuclear Criticality Safety, Versailles, France, September 20-24, 1999. 
29. B. L. Broadhead, "Feasibility Assessment of Burnup Credit in the Criticality Safety Analysis of Shipping Casks with Boiling Water Reactor Spent Fuel," Nucl. Technol. 110, 1 (1995).

30. B. L. Broadhead, K-infinite Trends with Burnup Enrichment and Cooling Time for BWR Fuel Assemblies, ORNL/M-6155, Lockheed Martin Energy Research Corp., Oak Ridge Natl. Lab., August 1998.

31. L. E. Wiles, N. J. Lombardo, C. M. Heeb, U. P. Jenquin, T. E. Michener, C. L. Wheeler, J. M. Creer, and R. A. McCann, BWR Spent Fuel Storage Cask Performance Test, PNL5777, Vol. II, Pacific Northwest Laboratory, June 1986.

32. R. J. Guenther et al., Characterization of Spent Fuel Approved Testing Material-ATM105, PNL-5109-105, Pacific Northwest Laboratory, 1991. 


\section{INTERNAL DISTRIBUTION}

$\begin{aligned} \text { 1. } & \text { S. M. Bowman } \\ \text { 2. } & \text { B. L. Broadhead } \\ \text { 3-7. } & \text { W. C. Carter } \\ \text { 8. } & \text { M. D. DeHart } \\ 9 . & \text { R. J. Ellis } \\ \text { 10. } & \text { M. B. Emmett } \\ \text { 11. } & \text { I. C. Gauld } \\ \text { 12. } & \text { J. C. Gehin } \\ \text { 13. } & \text { O. W. Hermann } \\ \text { 14. } & \text { D. T. Ingersoll } \\ \text { 15. } & \text { M. A. Kuliasha } \\ \text { 16. } & \text { S. K. Lichtenwalter } \\ \text { 17. } & \text { S. B. Ludwig } \\ \text { 18. } & \text { G. E. Michaels }\end{aligned}$

\author{
19. B. D. Murphy \\ 20-24. C. V. Parks \\ 25. L. M. Petrie \\ 26. R. T. Primm \\ 27. R. W. Roussin \\ 28. J. C. Ryman \\ 29. C. H. Shappert \\ 30-34. J. C. Wagner \\ 35. R. M. Westfall \\ 36. R. Q. Wright \\ 37. Central Research Library \\ 38. Laboratory Records - RC \\ 39-40. Laboratory Records - \\ For submission to OSTI
}

\section{EXTERNAL DISTRIBUTION}

41. H. A. Abderrahim, SCK-CEN, Fuel Research Department, Boeretang 200, Mol B-2400, BELGIUM

42. M. L. Anderson, Framatome Cogema Fuels, 1261 Town Center Drive, Las Vegas, Nevada 89134

43. S. Anton, Holtec International, 555 Lincoln Drive West, Marlton, NJ 08053

44. M. G. Bailey, Office of Nuclear Material Safety \& Safeguards, U.S. Nuclear Regulatory Commission, MS O13 D13, Washington, DC 20555

45. F. Barbry, Institut de Protection et de Surete Nucleaire, Department de Prevention et D'Etude des Accidents, Centre de Valduc - SRSC - 21120 IS Sur Tille, France

46. L. Barrett, Office of Civilian Radioactive Waste Management, RW-232 20545, U.S. Department of Energy, Washington, DC 20545

47. C. J. Benson, Bettis Atomic Power Laboratory, P.O. Box 79, West Mifflin, PA 15122

48. G. H. Bidinger, NUMEC, 17016 Cashell Road, Rockville, MD 20853

49. J. Boshoven, Transnuclear West, Inc., 39300 Civic Center Drive, Suite 280, Fremont, CA 94538

50. M. C. Brady Raap, Battelle, Pacific Northwest National Laboratory, P.O. Box 999 / MS K8-34, Richland, WA 99352 
51. J. B. Briggs, Idaho National Engineering \& Environmental Laboratory, P.O. Box 1625, MS-3890, Idaho Falls, ID 83415-3890

52. R. J. Cacciapouti, Yankee Atomic Electric Co., 1617 Worcester Rd., Framington, MA 01701

53. D. E. Carlson, U.S. Nuclear Regulatory Commission, Spent Fuel Project Office, MS O13 D13, Washington, DC 20555

54. R-T Chiang, GE Nuclear Energy, 175 Curtner Ave., San Jose, CA 95125

55. J. M. Conde López, Consejo de Seguridad Nuclear, Jefe de Area de Ingeniería Nuclear, Subdirección General de Technologia Nuclear, Justo Dorado, 11, 28040 Madrid, Spain

56. T. Congedo, Westinghouse Electric Company, Science and Technology Department, 1344 Beulah Road, Pittsburgh, PA 15235

57. D. R. Conners, Bettis Atomic Power Laboratory, P.O. Box 79, West Mifflin, PA 15122

58. P. Cousinou, Institut de Protection et de Sûreté Nucleaire, Départment de Recherches en Sécurité, CECI B.P. 6 - 92265 Fontenzy-Aux-Roses, Cedex, France

59. W. Davis, Framatome Cogema Fuels, 1261 Town Center Drive, Las Vegas, Nevada 89134

60. T. W. Doering, Framatome Cogema Fuels, 1261 Town Center Drive, Las Vegas, Nevada 89134

61. P. Finck, Argonne National Lab., 9700 S. Cass Ave., Bldg. 360, Argonne, IL 60439

62. E. K. Fujita, Reactor Analysis Division, Argonne National Laboratory, 9700 South Case Avenue, Argonne, IL 60439-4801

63. H. Geiser, Wissenschaftlich-Technische Ingenieurberatung GmbH, P.O. Box 13 40, 52410 Julich, Federal Republic of Germany

64. R. N. B. Gmal, Gesellschaft für Anlagen-und Reaktorsicherheit (GRS) mbH, Leiter der Gruppe Kritikalität, Forschungsgelände, 85748 Garching b. München

65. P. Grimm, Paul Scherrer Institute, CH-5232 Villigen Psi, Switzerland

66. N. Gulliford, Winfrith Technology Centre, 306/A32, AEA Technology PLC, Winfrith, Dorchester, Dorset DT2 8DH, United Kingdom

67. A. Haghighat, Pennsylvania State University, University Park, PA 16802

68. S. Hanauer, U.S. Department of Energy, RW-22, Washington, DC 20545

69. G. Harms, Sandia National Laboratory, PO Box 5800, Mail Stop 1143, Albuquerque, New Mexico 87185-1143

70. L. A. Hassler, Framatome Cogema Fuels, 3315 Old Forest Road, P.O. Box 10935, Lynchburg, VA 24506-0935

71. D. Henderson, Framatome Cogema, 1261 Town Center Drive, Las Vegas, Nevada 89134

72. S. Janski, Electricité de France, EDF Industry, Basic Design Department, 12-14, Avenue Dutriévoz, 69628 Villeurbanne, Cedex, France

73. E. Johnson, E. R. Johnson Associates, Inc., 9302 Lee Hwy, Suite 200, Fairfax, VA 22031

74. R. A. Knief, XE Corporation (XEC), P.O. Box 90818, Albuquerque, NM 87199 
75. H. Kühl, Wissenschaftlich-Technische Ingenieurberatung GMBH, Karl-HeinzBeckurts-Strasse 8, 52428 Jülich

76. W. H. Lake, Office of Civilian Radioactive Waste Management, U.S. Department of Energy, RW-46, Washington, DC 20585

77. D. B. Lancaster, Nuclear Consultants.com, 320 South Corl Street, State College, PA 16801

78. C. Lavarenne, Institut de Protection et de Sûreté Nucléaire, Department of Prevention and Studies of Accidents, Criticality Studies Division, CEA - 60-68, avenue de Général Leclerc, B.P. 6 - 92265, Fontenay - Aux - Roses, Cedex, France

79. Y. L. Liu, Argonne National Laboratory, 9700 S. Cass Ave., Bldg.308, Argonne, IL 60439-4825

80. M. Mason, Transnuclear, Two Skyline Drive, Hawthorne, NY 10532-2120

81. A. J. Machiels, Electric Power Research Institute, Advanced Nuclear Technology, Energy Conservation Division, 3412 Hillview Ave., Palo Alto, CA 94304-1395

82. P. Malesys, Transnucleaire, 9-11, rue Christophe Colomb, 75008 Paris, France

83. L. Markova, Ustav jaderneho vyzkumu Rez, Theoretical Reactor Physics, Nuclear Research Institute, Czech Republic, 25068 REZ

84. B. Martinotti, Transnucleaire, 9-11, rue Christophe Colomb, 75008, Paris, France

85. C. W. Mays, Framatome Cogema Fuels, 3315 Old Forest Road, P.O. Box 10935, Lynchburg, VA 24506-0935

86. J. N. McKamy, U.S. Department of Energy, Office of Engineering Assistance and Site Interface, EH-34, 19901 Germantown Rd., Germantown, MD 20874

87. N. B. McLeod, JAI Corporation, 4103 Chain Bridge Road, Suite 200, Fairfax, VA 22030

88. D. Mennerdahl, E. Mennerdahl Systems, Starvägen 12, S-183 57 Täby, Sweden

89. K. A. Neimer, Duke Engineering \& Services, 400 S. Tyron St., WC26B, P.O. Box 1004, Charlotte, NC 28201-1004

90-94. C. W. Nilsen, Office of Nuclear Regulatory Research, U.S. Nuclear Regulatory Commission, MS T10 K08, Washington, DC 20555

95. P. Noel, Framatome Cogema, 1261 Town Center Drive, Las Vegas, Nevada

96. I. Nojiri, Japan Nuclear Cycle Development Institute, Environment and Safety Division, Tokai Works, Muramatsu Tokai-mura, Naka-gun Ibaraki-ken 3191194, Japan

97. J. C. Neuber, SIEMENS AG, KWU NS-B, Berliner Str. 295-303, D-63067 OFFENBACH AM MAIN, Germany

98. Office of the Assistant Manager for Energy Research and Development, Department of Energy Oak Ridge Operations (DOE-ORO), P.O. Box 2008, Oak Ridge, TN 37831

99. H. Okuno, Japan Atomic Energy Research Institute, Department of Fuel Cycle, Safety Research, 2-4 Shirakata-Shirane, 319-1195 Tokai-mura, Naka-Gun, Ibaraki-ken, Japan

100. P. M. O'Leary, Framatome Technologies, 3315 Old Forest Road, P.O. Box 10935, Lynchburg, VA 24506-0935 
101. N. L. Osgood, U.S. Nuclear Regulatory Commission, Office of Nuclear Materials Safety and Safeguards, MS O13 D13, Washington, DC 20555

102. O. Ozer, Electric Power Research Institute, 3412 Hillview Ave., Palo Alto, CA 94304

103. T. Parish, Department of Nuclear Engineering, Texas A \& M University, College Station, TX 77843-3313

104. V. A. Perin, U.S. Nuclear Regulatory Commission, Office of Nuclear Material Safety and Safeguards, MS T10 K08, Washington, DC 20555

105. B. Petrovic, Westinghouse Electric Company, Science and Technology Department, 1344 Beulah Road, Pittsburgh, PA 15235

106. J. S. Philbin, Sandia National Laboratory, PO Box 5800, Mail Stop 1143, Albuquerque, New Mexico 87185-1143

107. F. Rahnema, Georgia Institute of Technology, George Woodruff School of Mechanical Engineering, Atlanta, GA 30332-0405

108. M. Rahimi, U.S. Nuclear Regulatory Commission, Office of Nuclear Material Safety and Safeguards, MS T7 F3, Washington, DC 20555

109. E. L. Redmond II, Holtec International, 555 Lincoln Drive West, Marlton, NJ 08053

110. C. Rombough, CTR Technical Services, Inc., 950 Sugarloaf Rd., Manitou Springs, CO 80829

111. D. Salmon, Framatome Cogema, 1261 Town Center Drive, Las Vegas, Nevada 89134

112. A. Santamarina, Commissariat A L'Energie Atomique, Nuclear Reactor Division, Reactor Studies Department, Reactor and Cycle Physics Service, CEA/CADARACHE/DRN/DER/SPRC Bat. 230, 13108 Saint-Paul-LezDurance, Cedex, France

113. E. Sartori, OECD/NEA Data Bank, Le Seine-Saint Germain, 12 Boulevard des Iles, F-92130 Issy-les-Moulineaux, France

114. H. H. Schweer, Bundesamt fuer Strahlenschutz, Willi Brandt Str. 5, D-38226 SALZGITTER, Germany

115. G. Sert, Institut de Protection et de Surete Nuclear, Department de Securite des Matieres Radioactives, B.P. 6 - 92265, Fontenay - AUX - Roses, Cedex France

116. D. N. Simister, Health and Safety Executive, Nuclear Installations Inspectorate, St Peter's House, Balliol Road, Bootle, Merseyside L20 3LZ

117. S. Sitaraman, GE Nuclear Energy, 175 Curtner Ave., San Jose, CA 95125

118. M. Smith, Virginia Power Co., P.O. Box 2666, Richmond, VA 23261

119. N. R. Smith, AEA Technology, A32 Winfrith, Dorchester, Dorset DT2 8DH, United Kingdom

120. J. T. Stewart, Department of Environment, Transport, and Re, RMTD, 4/18, GMH, 76 Marsham Street, London SW1P 4DR, United Kingdom

121. T. Suto, Power Reactor and Nuclear Fuel Development Corporation, Technical Service Division, Tokai Reprocessing Plant, Tokai Works, Tokai-Mura, Nakagun, Ibaraki-ken, Japan

122. H. Taniuchi, Kobe Steel, Ltd., 2-3-1 Shinhama, Arai-Cho, Takasago, 676 Japan

123. D. A. Thomas, Framatome Cogema, 1261 Town Center Drive, Las Vegas, Nevada 89134 
124. P. R. Thorne, British Nuclear Fuels plc (BNFL), Nuclear and Radiological Safety, R101 Rutherford House, Risley Warrington WA3 6AS, United Kingdom

125. J. R. Thornton, Duke Engineering \& Services, 230 S. Tyron St., P.O. Box 1004, Charlotte, NC 28201-1004

126. S. E. Turner, HOLTEC International, 230 Normandy Circle East, Palm Harbor, FL 34683

127. M. E. Wangler, U.S. Department of Energy, EH-33.2, Washington, DC 205850002

128. W-J. Weber, Gesellschaft fuer Anlagenund Reaktorsicheheit, Forschungsgelaende, Postfach 1328, D-85739 GARCHING, Germany

129. A. Wells, 2846 Peachtree Walk, Duluth, GA 30136

130. W. Weyer, Wissenschaftlich-Technische Ingenieurberatung GMBH, Mozartstrasse 13, 5177 Titz-Rodingen, Federal Republic of Germany

131. B. H. White, U.S. Nuclear Regulatory Commission, Spent Fuel Project Office, MS O13 D13, Washington, DC 20555

132. C. J. Withee, U.S. Nuclear Regulatory Commission, Spent Fuel Project Office, MS O13 D13, Washington, DC 20555

133. R. Yang, Electric Power Research Institute, 3412 Hillview Ave., Palo Alto, CA 94304 